\title{
Physiological, phenometric and productive changes in soybean crop due to the use of kinetin ${ }^{1}$
}

\author{
Luís Henrique Soares ${ }^{2}$, Durval Dourado Neto ${ }^{3}$, \\ Evandro Binotto Fagan², Walquíria Fernanda Teixeira ${ }^{3}$, Isabella Sabrina Pereira ${ }^{2}$
}

\section{ABSTRACT}

A fast growth in the use of substances that increase soybean yield through physiological or morphological changes, such as cytokinin, has taken place in recent years. This study aimed at assessing the effect of the application time of cytokinin as kinetin on soybean crops. The experiment was carried out under field conditions, using four treatments (control and kinetin at the vegetative stages $\mathrm{V}_{4}, \mathrm{~V}_{6}$ and $\mathrm{V}_{4}+\mathrm{V}_{6}$ ), with five replications, in completely randomized blocks. Physiological (nitrate reductase and peroxidase activity, $\mathrm{H}_{2} \mathrm{O}_{2}$ content and lipid peroxidation) and phenometric parameters (leaf and root dry mass), as well as yield, were evaluated. The application of kinetin at $\mathrm{V}_{4}, \mathrm{~V}_{6}$ or $\mathrm{V}_{4}+\mathrm{V}_{6}$ increased the activity of the nitrate reductase enzyme and reduced stress (evaluated via lipid peroxidation and hydrogen peroxide content), in addition to raising the dry matter content. All these characteristics resulted in increased yield. However, the most significant effects were caused by the application of kinetin at $\mathrm{V}_{6}$, which increased yield in $20 \%$, in relation to the control.

KEYWORDS: Glycine $\max (\mathrm{L}$.$) Merrill; cytokinin; nitrate$ reductase; peroxidase.

\section{INTRODUCTION}

Soybean [Glycine max (L.) Merrill] is the most widely grown oilseed in the world, with $80 \%$ of its production concentrated in the United States, Brazil and Argentina (USDA 2013). In Brazil, the average yield increases around $30 \mathrm{~kg} \mathrm{ha}^{-1}$ year-1 and is currently about $3,000 \mathrm{~kg} \mathrm{ha}^{-1}$, which is far from the plant's genetic potential of up to $20,391 \mathrm{~kg} \mathrm{ha}^{-1}$ (339.9 bags ha-1) (Navarro Júnior \& Costa 2002).

The yield potential of the crop is ruled by the genetic characteristics of its seeds. However,

\section{RESUMO}

Alterações fisiológicas, fenométricas e produtiva na cultura da soja devido ao uso de cinetina

Nos últimos anos, houve rápido crescimento na utilização de substâncias que buscam aumentar a produtividade de soja, como as citocininas, seja por alterações fisiológicas ou morfológicas. Objetivou-se avaliar o efeito da época de aplicação de citocinina na forma de cinetina, na cultura da soja. O experimento foi realizado em condições de campo, utilizando-se quatro tratamentos (controle e cinetina nos estágios vegetativos $\mathrm{V}_{4}, \mathrm{~V}_{6}$ e $\mathrm{V}_{4}+\mathrm{V}_{6}$ ), com cinco repetições, em blocos inteiramente casualizados. Foram realizadas avaliações fisiológicas (atividade de nitrato redutase e peroxidase, teor de $\mathrm{H}_{2} \mathrm{O}_{2}$ e peroxidação de lipídios) e fenométricas (massa de matéria seca de raiz e folhas), além da produtividade. A aplicação de cinetina em $\mathrm{V}_{4}, \mathrm{~V}_{6}$ ou $\mathrm{V}_{4}+\mathrm{V}_{6}$ proporcionou incremento na atividade da enzima nitrato redutase, redução do estresse (avaliado por meio da peroxidação lipídica e teor de peróxido de hidrogênio) e aumento no teor de massa de matéria seca. Todas essas características repercutiram no aumento da produtividade. Contudo, os efeitos mais expressivos foram causados pela aplicação de cinetina $\mathrm{em} \mathrm{V}_{6}$, que proporcionou incremento de $20 \%$ na produtividade, em relação ao controle.

PALAVRAS-CHAVE: Glycine $\max ($ L.) Merrill; citocinina; nitrato redutase; peroxidase.

conditions in the growing environment, such as temperature, water regime, photoperiod, soil chemical and physical properties, as well as competition with other plants, decrease its yield to the mean values currently seen. Some studies have recorded yields of $10,760 \mathrm{~kg} \mathrm{ha}^{-1}$ (Haegele \& Below 2013). This indicates the possibility of exploiting the genetic characteristics of the crop through physiological management.

Within this context, physiological stimulation through the use of hormones is one of the strategies adopted. This is because hormones act as signaling

1. Manuscript received in Aug./2016 and accepted for publication in Mar./2017 (http://dx.doi.org/10.1590/1983-40632016v4742790).

2. Centro Universitário de Patos de Minas, Patos de Minas, MG, Brazil.E-mails: luishenriqueagro@hotmail.com, evbinotto@yahoo.com.br.

3. Universidade de São Paulo, Escola Superior de Agricultura Luiz de Queiroz, Departamento de Produção Vegetal, Piracicaba, SP, Brazil.E-mails: d.dourado@gmail.com,walquiria_bio@hotmail.com. 
molecules in plants and may cause physiological changes, such as modulating nitrogen assimilation and antioxidant metabolism, among others, which affect carbon metabolism (dry mass accumulation and reallocation to the beans) and potentially increase yield (Soares 2014).

Cytokinins have been used to achieve this goal. The functions of these hormones include everything from promoting apical meristem growth to cell cycle regulation and nutrient mobilization, controlling senescence and the formation of root nodules in nitrogen-fixing plants (Zwack \& Rashotte 2013, Cortleven \& Schmülling 2015). Moreover, recent studies indicate that this hormone may modulate antioxidant metabolic pathways, reducing the stress level of plants (O’Brien \& Benková 2013, Alazem \& Lin 2015, Zwack \& Rashotte 2015). Taken together, these functions demonstrate that using the hormone may cause changes that lead to a higher yield in plants. In addition, the growth stage at which these growth regulators are applied is also an important point to be studied, since its effect may be modified as a function of the time they are applied and the crop variety used.

In this respect, the present study aimed at assessing the effect of the stage of kinetin application on the physiological and phenometric parameters and yield of soybean crops.

\section{MATERIAL AND METHODS}

The experiment was conducted in an experimental field of the Centro Universitário de Patos de Minas, in Patos de Minas, Minas Gerais State, Brazil (18'36'36"S, 46²9'11' W and $890 \mathrm{~m}$ of altitude), from November 2014 to May 2015, in a Dystrophic Red Latosol (Oxisol) (45\% of clay, $36 \%$ of silt and $19 \%$ of sand) (Embrapa 2006). According to the Köppen's classification, Patos de
Minas has a humid subtropical climate (Cwa), with an average annual rainfall of around $1,400 \mathrm{~mm}$, as well as average, maximum and minimum annual temperatures of $21.1{ }^{\circ} \mathrm{C}, 27.8^{\circ} \mathrm{C}$ and $16.3{ }^{\circ} \mathrm{C}$, respectively (Souza et al. 2005).

Maize was the summer crop grown in the experimental area in the previous year, used for silage and forage (Brachiaria decumbens) in the winter. Desiccation was performed at 25 days before planting, using Roundup Transorb ${ }^{\circledR}$ (glyphosate $480 \mathrm{~g}$ a.i. $\left.\mathrm{L}^{-1}\right)$ at a dose of $4 \mathrm{~L} \mathrm{ha}^{-1}$.

The NS-7114-RR soybean cultivar was used, with spacing of $0.45 \mathrm{~m}$ between rows and a population of 380,000 plants at harvest. The variety used belongs to the maturity group 7.1, with undetermined growth habit and 120-day cycle. Prior to planting, seeds were treated with inoculant [Atmo $^{\circledR}$ - Bradyrhizobium japonicum - SEMIA 5079 and $\left.5080\left(5 \times 10^{9} \mathrm{CFU} \mathrm{mL}^{-1}\right)\right]$ at a dose of $0.5 \mathrm{~mL} \mathrm{~kg}^{-1}$ of seeds, fungicide + insecticide [Standak Top ${ }^{\circledR}$ fipronil $\left(250 \mathrm{~g} \mathrm{~L}^{-1}\right)+$ methyl thiophanate $\left(225 \mathrm{~g} \mathrm{~L}^{-1}\right)+$ pyraclostrobin $\left.\left(25 \mathrm{~g} \mathrm{~L}^{-1}\right)\right]$ at $2 \mathrm{~mL} \mathrm{~kg}^{-1}$ of seeds and molybdenum + cobalt + amino acids + algae extract [Exion DA ${ }^{\circledR}-$ molybdenum $\left(75.6 \mathrm{~g} \mathrm{~L}^{-1}\right)+$ cobalt $\left(7.56 \mathrm{~g} \mathrm{~L}^{-1}\right)+$ amino acids $\left(163.8 \mathrm{~g} \mathrm{~L}^{-1}\right)+$ algae extract $\left.\left(37.8 \mathrm{~g} \mathrm{~L}^{-1}\right)\right]$. Soil samples were also collected before planting, to determine their chemical characteristics, in line with the methodology proposed by Embrapa (2011). According to the soil analysis (Table 1), liming to correct soil acidity was not required. The fertilizer used was $450 \mathrm{~kg} \mathrm{ha}^{-1}$ of the formulation $08: 30: 10+3.26 \%$ of $\mathrm{Ca}+4.25 \%$ of $\mathrm{S}+0.2 \%$ of $\mathrm{B}+0.2 \%$ of $\mathrm{Zn}$.

For weed management, Roundup Transorb ${ }^{\circledR}$ [glyphosate $\left(480 \mathrm{~g} \mathrm{~L}^{-1}\right)$ ] was applied at 14 and 35 days after sowing (DAS), at a dose of $2 \mathrm{~L} \mathrm{ha}^{-1}$. Pests were controlled using Fastac Duo ${ }^{\circledR}$ [acetamiprid $\left(100 \mathrm{~g} \mathrm{~L}^{-1}\right)+$ alpha-cypermethrin $\left.\left(200 \mathrm{~g} \mathrm{~L}^{-1}\right)\right]$, at a dose of $250 \mathrm{~mL}$ c.p. ha ${ }^{-1}+$ Pirate $^{\circledR}$ [chlorfenapyr

Table 1. Results of soil analysis $(0-20 \mathrm{~cm})$ in the experimental area.

\begin{tabular}{|c|c|c|c|c|c|c|c|}
\hline $\mathrm{pH}$ & P-Mel & Rem-P & $\mathrm{K}^{+}$ & $\mathrm{Ca}^{2+}$ & $\mathrm{Mg}^{2+}$ & $\mathrm{Al}^{3+}$ & $\mathrm{H}+\mathrm{Al}$ \\
\hline$\left(\mathrm{H}_{2} \mathrm{O}\right)$ & \multicolumn{3}{|c|}{$\mathrm{mg} \mathrm{dm}^{-3}$} & \multicolumn{4}{|c|}{$-\mathrm{cmol}_{\mathrm{c}} \mathrm{dm}^{-3}$} \\
\hline 5.60 & 10.23 & 4.94 & 85.70 & 2.94 & 0.56 & 0.02 & 1.30 \\
\hline $\mathrm{BS}$ & \multicolumn{2}{|r|}{$\mathrm{t}$} & $\mathrm{T}$ & $\mathrm{V}$ & \multicolumn{2}{|c|}{$\mathrm{m}$} & $\mathrm{OM}$ \\
\hline \multicolumn{4}{|c|}{$-\mathrm{cmol}_{\mathrm{c}} \mathrm{dm}^{-3}$} & \multicolumn{3}{|c|}{$\%$} & dag $\mathrm{kg}^{-1}$ \\
\hline 3.72 & & 3.74 & 5.02 & 74.11 & & & 3.12 \\
\hline
\end{tabular}

Extractors: $\mathrm{K}$ and P-assimilable by Mehlich-1; remaining $\mathrm{P}$ in $10 \mathrm{mmol} \mathrm{L}-1$ of a $\mathrm{CaCl}_{2}$ solution; exchangeable $\mathrm{Ca}^{2+}, \mathrm{Mg}^{2+}$ and $\mathrm{Al}^{3+}$ content extracted by $\mathrm{KCl}$; potential acidity by calcium acetate; and total organic matter by titration. 
$\left.\left(240 \mathrm{~g} \mathrm{~L}^{-1}\right)\right]$ at $500 \mathrm{~mL}$ c.p. ha ${ }^{-1}$, at 84 days after sowing.

Diseases were controlled by applying Opera ${ }^{\circledR}$ [pyraclostrobin (133 $\left.\mathrm{g} \mathrm{L}^{-1}\right)+$ epoxiconazole $\left.\left(50 \mathrm{~g} \mathrm{~L}^{-1}\right)\right]$ at 54 DAS and Orkestra ${ }^{\circledR}$ [fluxapyroxad $\left(167 \mathrm{~g} \mathrm{~L}^{-1}\right)+$ pyraclostrobin $\left.\left(333 \mathrm{~g} \mathrm{~L}^{-1}\right)\right]$ at $300 \mathrm{~mL}$ c.p. ha ${ }^{-1}$ at 70 and 84 DAS. During the insecticide and fungicide application, $500 \mathrm{~mL}$ c.p. ha $^{-1}$ of Assist $^{\circledR}$ was added to the spray solution.

Each experimental plot was made up of four 7-meter-long rows spaced $0.45 \mathrm{~m}$ apart, totaling $12.6 \mathrm{~m}^{2}$. The study area in each plot consisted of the center rows, disregarding $0.5 \mathrm{~m}$ at either end. A randomized block design was adopted, consisting of four treatments $\left(T_{1}\right.$ - control - no application); $\mathrm{T}_{2}$ - kinetin at $\mathrm{V}_{4} ; \mathrm{T}_{3}$ - kinetin at $\mathrm{V}_{6} ; \mathrm{T}_{4}$ - kinetin at $\mathrm{V}_{4}+\mathrm{V}_{6}$ ), with 5 replications for each treatment. The kinetin dose applied was $50 \mathrm{mg} \mathrm{ha}^{-1}$, based on existing commercial products used for soybean cultivation. Applications were carried out at 27 and 34 DAS, corresponding to the stages $\mathrm{V}_{4}$ (fourth node, 3 fully developed trifoliate leaves) and $\mathrm{V}_{6}$ (sixth node, 5 fully developed trifoliate leaves) (Fehr \& Caviness 1977), respectively.

Leaf application was performed using a $\mathrm{CO}_{2}$ pressurized backpack sprayer, with a $2.25 \mathrm{~m}$-long boom and four spray nozzles, at a constant pressure of 2 bars. A spray volume of $200 \mathrm{~L} \mathrm{ha}^{-1}$ was used for all applications.

Biochemical analyses were carried out on leaves from five plants in each block. The samples were homogenized and the material was used to assess the nitrate reductase activity (Mulder et al. 1959) at 39 and 53 DAS, as well as hydrogen peroxide (Alexieva et al. 2001) and lipid peroxidation (Heath \& Packer 1968) at 89 DAS. Antioxidant enzyme activity was also determined at 89 DAS, based on the extraction of plant material (Kar \& Mishra 1976). The same material was used to determine the total soluble protein content (Bradford 1976) and peroxidase activity (Teisseire \& Guy 2000).

At 40, 67 and 91 DAS, four plants were collected from each plot to determine root and leaf dry mass. A furrow was dug alongside the plants during the collection process to avoid root loss. The plant parts were separated after collection and stored individually in paper bags. The different parts were dried using a standard forced air oven at $65^{\circ} \mathrm{C}$, until constant weight.
At the end of the crop cycle (117 DAS), plants were manually harvested from the two center rows of each plot, disregarding $0.5 \mathrm{~m}$ at either end. Next, the plants were threshed using a tractormounted thresher. The water content of the beans was determined and yield (production per unit area) calculated with water content corrected to $13 \%$ $\left(0.13 \mathrm{~g} \mathrm{~g}^{-1}\right)$. The beans were weighed using a digital balance accurate to $0.01 \mathrm{~g}$.

Statistical analyses were performed with the Sisvar ${ }^{\circledR}$ software (Ferreira 2010). The normality of Anova residuals and homogeneity between variances were analyzed using the Shapiro-Wilk and Levene's tests, respectively, both at $1 \%$. Next, analysis of variance was conducted and means were compared via standard deviation of the mean and the Tukey test at $5 \%$.

\section{RESULTS AND DISCUSSION}

At 39 DAS, the highest nitrate reductase activity recorded was for the kinetin treatment at $\mathrm{V}_{4}+\mathrm{V}_{6}$. In this case, the increases observed were $16 \%, 14 \%$ and $79 \%$, in relation to the control, kinetin at $\mathrm{V}_{4}$ and kinetin at $\mathrm{V}_{6}$, respectively (Table 2). At 53 DAS, results were higher for all treatments, in relation to the control, with nitrate reductase activity increases of $75 \%, 28 \%$ and $51 \%$, respectively for the application at $\mathrm{V}_{4}, \mathrm{~V}_{6}$ and $\mathrm{V}_{4}+\mathrm{V}_{6}$.

Nitrate reductase is considered an important sensor capable of measuring the physiological status of plants, since the enzyme depends directly on energy from photosynthesis (Marschner 2012). Thus, the treatments that produced the highest nitrate reductase activity also influenced the physiological

Table 2. Nitrate reductase activity at 39 and 53 days after sowing (DAS), in soybean plants submitted to kinetin application at different stages.

\begin{tabular}{|c|c|c|}
\hline \multirow{3}{*}{ Treatment } & \multicolumn{2}{|c|}{ Nitrate reductase activity } \\
\hline & $39 \mathrm{DAS}$ & $53 \mathrm{DAS}$ \\
\hline & \multicolumn{2}{|c|}{$-\mu \mathrm{g}\left[\mathrm{N}-\mathrm{NO}_{2}\right] \mathrm{g}^{-1}[$ fresh mass $] \mathrm{h}^{-1}$} \\
\hline Control & $0.68 \mathrm{~b}^{(1)}$ & $0.66 \mathrm{~d}$ \\
\hline Kinetin $\left(\mathrm{V}_{4}\right)$ & $0.69 \mathrm{~b}$ & $1.17 \mathrm{a}$ \\
\hline $\operatorname{Kinetin}\left(\mathrm{V}_{6}\right)$ & $0.44 \mathrm{c}$ & $0.86 \mathrm{c}$ \\
\hline Kinetin $\left(\mathrm{V}_{4}+\mathrm{V}_{6}\right)$ & $0.79 \mathrm{a}$ & $1.01 \mathrm{~b}$ \\
\hline $\mathrm{MSD}^{(2)}$ & 0.09 & 0.04 \\
\hline $\mathrm{CV}(\%)$ & 7.16 & 4.12 \\
\hline
\end{tabular}

(1) Means followed by the same letter in the rows do not differ according to the Tukey test $(\mathrm{p}<0.05) ;{ }^{(2)} \mathrm{MSD}=$ minimum significant difference. 
potential of the plant. The highest nitrate reductase activity, if compared to the control, was observed for the kinetin application at $\mathrm{V}_{4}+\mathrm{V}_{6}$, suggesting that consecutive applications of the hormone are necessary to maintain high levels of the enzyme.

Researches using other cytokinins also demonstrate the effect of this hormone on the nitrate reductase activity. Arabdopsis thaliana plants grown in a medium containing benzyladenine, or submitted to leaf application of the hormone, showed a 3 to 14-fold increase in the activity of this enzyme (Yu et al. 1998), what is attributed to the effect of benzyladenine on the Nial gene expression, which encodes the expression of nitrate reductase.

Maintaining the nitrate reductase activity is essential for nitrogen assimilation through nitrate in the soil. This affects the yield of soybean plants, despite their ability to obtain $\mathrm{N}$ via biological fixation, given the positive correlation between yield and nitrogen assimilation in the growth stage $\mathrm{R}_{2}$. This occurs because, according to Fabre \& Planchon (2000), there is a sharp decline in the biological nitrogen fixation after $\mathrm{R}_{2}$, accompanied by increased nitrate assimilation up to the stage $\mathrm{R}_{6}$. Additionally, the authors found a correlation between biological fixation in $\mathrm{R}_{2}$ and $\mathrm{R}_{5}$ and protein content in the beans. Although this correlation has not been observed for nitrogen assimilation via soil nitrate, these results indicate that it is vital to maximize the nitrogen metabolism during the reproductive phase, in systems with high yield potential.

Cytokinins may also be important in maintaining the physiological activity of plants. Synthesis of this hormone is induced by stress, prompting an increase in the nitrate reductase activity. This characteristic was observed in rice plants exhibiting overexpression of the ipt gene (which encodes cytokinin synthesis). Under water stress, these plants exhibited a 3-fold increase in the nitrate reductase activity, when compared to wild plants (Reguera et al. 2013).

In addition to the aforementioned benefits, the use of kinetin also affected the oxidative metabolism (peroxidase activity, hydrogen peroxide content and lipid peroxidation). The use of kinetin in the stages $\mathrm{V}_{4}$ and $\mathrm{V}_{6}$ resulted in a greater peroxidase activity. The average increase in these treatments, in relation to the others, was $43 \%$ (Table 3 ). Wheat leaves, in a medium containing a different cytokinin $\left(10^{-1} \mathrm{M}\right.$ of benzylaminopurine), exhibited an increase in catalase and ascorbate peroxidase and reduced the hydrogen peroxide content, resulting in a lower percentage of electrolyte loss via membrane (Zavaleta-Mancera et al. 2007).

The decline in superoxide radicals produces hydrogen peroxide, a moderately reactive oxygen species, which causes oxidative stress. One of the effects of hydrogen peroxide is enzyme inactivation via the oxidation of thiol groups. However, at low concentrations, hydrogen peroxide acts as a signaling molecule for different plant processes, such as senescence, photorespiration, photosynthesis, stomatal movement, cell cycle, development and tolerance to different biotic and abiotic stresses. All stages of kinetin application reduced the hydrogen peroxide concentration, with declines of $20 \%, 24 \%$ and $34 \%$, respectively at $\mathrm{V}_{4}, \mathrm{~V}_{6}$ and $\mathrm{V}_{4}+\mathrm{V}_{6}$ (Table 3). As such, the rise in the peroxidase activity on kinetin application at $\mathrm{V}_{4}$ or $\mathrm{V}_{6}$ reduced hydrogen peroxide levels in these treatments. However, hydrogen peroxide levels were low in the treatment $\mathrm{V}_{4}+\mathrm{V}_{6}$, where no changes in peroxidase activity were observed. This means that alternative pathways, such as catalase, may have acted to reduce the levels of this free radical, leading to a decrease in stress.

Table 3. Peroxidase activity, hydrogen peroxide content $\left(\mathrm{H}_{2} \mathrm{O}_{2}\right)$ and lipid peroxidation at 89 days after sowing in soybean, after kinetin application at different growth stages.

\begin{tabular}{lccc}
\hline \multirow{2}{*}{ Treatment } & Peroxidase & Hydrogen peroxide & Lipid peroxidation \\
\cline { 2 - 4 } & $\mu$ mol [purpurogallin] $\mathrm{min}^{-1} \mathrm{mg}^{-1}$ [protein] & $\mu$ mol g $\mathrm{g}^{-1}[$ fresh mass] & nmol [TBARS] $\mathrm{g}^{-1}[\mathrm{fresh}$ mass] \\
\hline Control & $0.114 \mathrm{~b}^{(1)}$ & $87.1 \mathrm{a}$ & $108.1 \mathrm{ab}$ \\
Kinetin $\left(\mathrm{V}_{4}\right)$ & $0.163 \mathrm{a}$ & $69.4 \mathrm{~b}$ & $104.2 \mathrm{ab}$ \\
Kinetin $\left(\mathrm{V}_{6}\right)$ & $0.180 \mathrm{a}$ & $66.1 \mathrm{c}$ & $101.2 \mathrm{~b}$ \\
Kinetin $\left(\mathrm{V}_{4}+\mathrm{V}_{6}\right)$ & $0.125 \mathrm{~b}$ & $57.8 \mathrm{~d}$ & $111.8 \mathrm{a}$ \\
\hline MSD $^{(2)}$ & 0.03 & 3.17 & 7.56 \\
\hline $\mathrm{CV}(\%)$ & 9.82 & 2.41 & 3.79 \\
\hline${ }^{(1)}$ Means followed by the same letter in the rows do not differ according to the Tukey test $(\mathrm{p}<0.05) ;{ }^{(2)} \mathrm{MSD}=$ minimum significant difference.
\end{tabular}


Plant stress can be measured through lipid peroxidation, meaning that the higher the lipid peroxidation the greater the stress. Thus, the kinetin applications performed in the present study altered this variable, with the highest lipid peroxidation observed in the treatment $\mathrm{V}_{4}+\mathrm{V}_{6}$, although there was no difference between this treatment and the control or $\mathrm{V}_{4}$ (Table 3).

An increase in the cytokinin supply can stimulate the salicylic acid synthesis, as observed by Masuta et al. (1995) in tobacco plants. Salicylic acid promotes the accumulation of reactive oxygen species, which act as signaling molecules for the expression of genes related to hormone functions (Mittler 2002). The application of high concentrations of salicylic acid (more than $1 \mathrm{mM}$ ) results in high reactive oxygen species levels, causing a decline in the detoxification capacity, cell death and greater oxidative stress (Mittler 2002).

Analysis at 40 DAS showed that kinetin increased the root dry mass for all application stages, in relation to the control (Table 4).

At 67 DAS, the kinetin application at $\mathrm{V}_{6}$ increased the root dry mass by $24 \%, 23 \%$ and $69 \%$, in relation to $\mathrm{V}_{4}$, control and $\mathrm{V}_{4}+\mathrm{V}_{6}$, respectively. An increase in root dry mass was observed for the kinetin treatment at $\mathrm{V}_{4}+\mathrm{V}_{6}$, at $91 \mathrm{DAS}$, although there was no difference in relation to $\mathrm{V}_{6}$ (Table 4).

The rise in the root dry mass accumulation after kinetin application may be related to a greater nitrate reductase activity and lower stress levels, which may have resulted in higher net photosynthesis in the treated plants. High root growth is important because it improves the plant ability to absorb water and nutrients. Plants with

Table 4. Root dry mass at 40, 67 and 91 days after sowing (DAS), in soybean plants submitted to kinetin application at different growth stages.

\begin{tabular}{llll}
\hline \multirow{2}{*}{ Treatment } & \multicolumn{3}{c}{ Root dry mass } \\
\cline { 2 - 4 } & 40 DAS & 67 DAS & $91 \mathrm{DAS}$ \\
\cline { 2 - 4 } & \multicolumn{4}{c}{ g plant $^{-1}$} \\
\hline Control & $0.49 \mathrm{~b}^{(1)}$ & $1.54 \mathrm{~b}$ & $0.93 \mathrm{c}$ \\
Kinetin $\left(\mathrm{V}_{4}\right)$ & $0.75 \mathrm{a}$ & $1.54 \mathrm{~b}$ & $0.99 \mathrm{bc}$ \\
Kinetin $\left(\mathrm{V}_{6}\right)$ & $0.72 \mathrm{a}$ & $1.91 \mathrm{a}$ & $1.08 \mathrm{ab}$ \\
Kinetin $\left(\mathrm{V}_{4}+\mathrm{V}_{6}\right)$ & $0.74 \mathrm{a}$ & $1.13 \mathrm{c}$ & $1.14 \mathrm{a}$ \\
\hline MSD $^{(2)}$ & 0.10 & 0.08 & 0.11 \\
\hline $\mathrm{CV}(\%)$ & 8.12 & 5.77 & 7.73 \\
\hline (1) & Means followed by the same letter in the rows do not differ according to the \\
Tukey test $(\mathrm{p}<0.05) ;{ }^{(2)} \mathrm{MSD}=$ minimum significant difference.
\end{tabular}

a substantial root surface area are more tolerant to possible stresses due to their superior soil exploitation ability (Larcher 2004), ensuring a better growth in roots. Additionally, large root systems may provide a greater nodule formation, leading to increased nitrogen assimilation (Fagan et al. 2015). As such, an increased accumulation of root dry mass, associated with a rise in the nitrate reductase activity and reduced stress levels, resulted in a greater leaf dry mass accumulation (Table 5).

At 40 DAS, all the treatments increased the leaf dry mass accumulation, in relation to the control. However, no difference was observed among $\mathrm{V}_{4}, \mathrm{~V}_{6}$ and $\mathrm{V}_{4}+\mathrm{V}_{6}$ (Table 5).

Kinetin application at 67 DAS showed the highest dry mass accumulation, in relation to the other treatments, and $18.8 \%$, in relation to the control (Table 5).

Cytokinins maintain membrane integrity, preventing the transport of proteases from the vacuole to the cytoplasm and hydrolyzing soluble proteins from plasma membranes, chloroplasts and mitochondria. Additionally, the hormone blocks fatty acid (phospholipids) oxidation, prevents membrane oxidation and degradation, inhibits the formation and breakdown of free radicals, such as superoxides $\left(\mathrm{O}_{2}^{-}\right)$ and hydroxyls $\left(\mathrm{OH}^{-}\right)$, inhibits chlorophyll degradation and promotes protein and nitrate reductase activity synthesis (Zavaleta-Mancera et al. 2007).

Moreover, leaf maintenance may be related to increased acid invertase activity. Cytokinins stimulate the activity of this enzyme, which catalyzes the cleavage of sucrose into hexoses, when it is released into sink organs (Lara et al. 2004). Thus, the application of cytokinins may keep leaves green for

Table 5. Leaf dry mass at 40, 67 and 91 days after sowing (DAS), in soybean plants submitted to kinetin application at different stages.

\begin{tabular}{llll}
\hline \multirow{2}{*}{ Treatment } & \multicolumn{3}{c}{ Leaf dry mass } \\
\cline { 2 - 4 } & 40 DAS & 67 DAS & 91 DAS \\
\cline { 2 - 4 } & \multicolumn{3}{c}{ g plant $^{-1}$} \\
\hline Control & $2.11 \mathrm{~b}^{(1)}$ & $5.15 \mathrm{~b}$ & $3.03 \mathrm{a}$ \\
Kinetin $\left(\mathrm{V}_{4}\right)$ & $2.30 \mathrm{a}$ & $4.59 \mathrm{~b}$ & $3.16 \mathrm{a}$ \\
Kinetin $\left(\mathrm{V}_{6}\right)$ & $2.37 \mathrm{a}$ & $6.13 \mathrm{a}$ & $3.96 \mathrm{a}$ \\
Kinetin $\left(\mathrm{V}_{4}+\mathrm{V}_{6}\right)$ & $2.39 \mathrm{a}$ & $4.62 \mathrm{~b}$ & $3.12 \mathrm{a}$ \\
\hline MSD $^{(2)}$ & 0.12 & 0.96 & 0.36 \\
\hline $\mathrm{CV}(\%)$ & 5.75 & 10.0 & 6.20 \\
\hline${ }^{(1)}$ Means followed by the same letter in the rows do not differ according to the \\
Tukey test $(\mathrm{p}<0.05) ;{ }^{(2)} \mathrm{MSD}=$ minimum significant difference.
\end{tabular}


longer and stimulate the release of energy into sink organs, what could lead to a greater yield.

According to Evans (1989), the production of dry matter by crops, in general, is primarily linked to nitrogen availability, in conjunction with greater $\mathrm{CO}_{2}$ assimilation via photosynthesis. In soybeans, increased dry mass and leaf area during seed filling are reported by Nelson (1986) as a major factor for improving crop yield. All the kinetin treatments were superior to the control by an average of $16.9 \%$ (Table 6). However, considering all the results together, the high dry mass accumulation and low stress level provided by the kinetin at $\mathrm{V}_{6}$ makes this the most promising application stage.

The accumulation of dry matter from the stage $\mathrm{R}_{1}$ and during $\mathrm{R}_{5}$ is an important component in estimating soybean yield, primarily due to a greater light interception and photoassimilate partitioning to the reproductive organs, which contribute to optimizing yield (Board \& Modali 2005).

The rise in the nitrate reductase activity (greater nitrogen assimilation), associated with a larger leaf area, may have increased the photosynthetic area, raising the net photosynthesis and resulting in a greater production of sugars for subsequent transport to the developing sink organs, in this case seed filling.

Figure 1 shows a mode of action for kinetin, whose application increased the nitrogen assimilation (Table 2). In addition, the hormone maintained the stress levels of the plants under study, being evident in the high peroxidase activity (Table 3 ) and low hydrogen peroxide content (Table 3), with a slight reduction in lipid peroxidation (Table 3 ). High nitrogen assimilation, associated with low stress levels, resulted in a greater root (Table 4) and leaf dry mass accumulation (Table 5), improving plant yield (Table 6).

Table 6. Soybean yield after kinetin application at different growth stages.

\begin{tabular}{lc}
\hline \multicolumn{1}{c}{ Treatment } & Yield \\
\cline { 2 - 2 } & $\mathrm{kg} \mathrm{ha}^{-1}$ \\
\hline Control & $3,540.6 \mathrm{~b}^{(1)}$ \\
Kinetin $\left(\mathrm{V}_{4}\right)$ & $4,124.3 \mathrm{a}$ \\
Kinetin $\left(\mathrm{V}_{6}\right)$ & $4,247.4 \mathrm{a}$ \\
Kinetin $\left(\mathrm{V}_{4}+\mathrm{V}_{6}\right)$ & $4,042.1 \mathrm{a}$ \\
\hline MSD $^{(2)}$ & 217.7 \\
\hline $\mathrm{CV}(\%)$ & 5.91 \\
\hline${ }^{(1)}$ Means followed by the same letter do not differ according to the Tukey test \\
(p $<0.05)$; ${ }^{(2)}$ MSD = minimum significant difference.
\end{tabular}

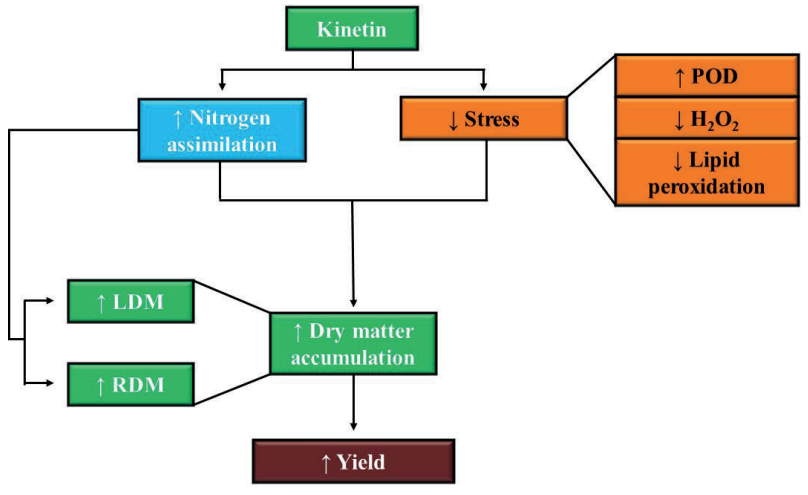

Figure 1. Mode of action of kinetin applied at different stages of soybean growth. POD: peroxidase; $\mathrm{H}_{2} \mathrm{O}_{2}$ : hydrogen peroxide; RDM: root dry mass; LDM: leaf dry mass.

\section{CONCLUSION}

The kinetin application to soybean crops at $\mathrm{V}_{4}$, $\mathrm{V}_{6}$ or $\mathrm{V}_{4}+\mathrm{V}_{6}$ increases the nitrate reductase activity, reduces stress levels and increases the dry mass accumulation, resulting in a high yield. However, the best effect on yield was observed for the kinetin application at $\mathrm{V}_{6}$, with a $20 \%$ increase, in relation to the control.

\section{REFERENCES}

ALAZEM, M.; LIN, N. S. Roles of plant hormones in the regulation of host-virus interactions. Molecular Plant Pathology, v. 16, n. 5, p. 529-540, 2015.

ALEXIEVA, V. et al. The effect of drought and ultraviolet radiation on growth and stress markers in pea and wheat. Plant, Cell \& Environment, v. 24, n. 12, p. 1337-1344, 2001.

BOARD, J. E.; MODALI, H. Dry matter accumulation predictors for optimal yield in soybean. Crop Science, v. 45, n. 1, p. 1790-1799, 2005.

BRADFORD, M. M. A rapid and sensitive method for quantification of microgram quantities of protein utilizing the principle of protein-dye-binding. Analytical Biochemistry, v. 72, n. 1, p. 248-254, 1976.

CORTLEVEN, A.; SCHMÜLLING, T. Regulation of chloroplast development and function by cytokinin. Journal of Experimental Botany, v. 66, n. 1, p. 1-15, 2015.

EMPRESA BRASILEIRA DE PESQUISA AGROPECUÁRIA (Embrapa). Centro Nacional de Pesquisa de Solos. Sistema brasileiro de classificação de solos. 2. ed. Rio de Janeiro: Embrapa Solos, 2006. 
EMPRESA BRASILEIRA DE PESQUISA AGROPECUÁRIA (Embrapa). Centro Nacional de Pesquisas de Solos. Manual de métodos de análises de solos. 2. ed. Rio de Janeiro: Embrapa Solos, 2011.

EVANS, J. R. Photosynthesis and nitrogen relationships in leaves of $\mathrm{C}_{3}$ plants. Oecologia, v. 78, n. 9, p. 9-19, 1989.

FABRE, F.; PLANCHON, C. Nitrogen nutrition, yield and protein content in soybean. Plant Science, v. 152, n. 1, p. 51-58, 2000.

FAGAN, E. B. et al. Fisiologia vegetal: reguladores vegetais. São Paulo: Andrei, 2015.

FEHR, W. R.; CAVINESS, C. E. Stages of soybean development. Ames: Iowa State University, 1977. (Special report, 80).

FERREIRA, D. F. Sisvar: sistema de análise de variância. Versão 5.3. Lavras: UFLa, 2010.

HAEGELE, J. W.; BELOW, F. E. The six secrets of soybean success: improving management practices for high yield soybean production. 2013. Available at: $<$ http:// cropphysiology.cropsci.illinois.edu/documents/2012\%20 Six $\% 20$ Secrets $\% 20$ of $\% 20$ Soybean $\% 20$ Success $\% 20$ report.pdf>. Access on: Nov. 8, 2015.

HEATH, R. L.; PACKER, L. Photoperoxidation in isolated chloroplasts: I. Kinetics and stoichiometry of fatty acid peroxidation. Archives in Biochemistry and Biophysics, v. 125, n. 1, p. 189-198, 1968.

KAR, M.; MISHRA, D. Catalase, peroxidase, and polyphenoloxidase activities during rice leaf senescence. Plant Physiology, v. 57, n. 2, p. 315-319, 1976.

LARA, M. E. B. et al. Extracellular invertase is an essential component of cytokinin-mediated delay of senescence. The Plant Cell, v. 16, n. 5, p. 1276-1287, 2004.

LARCHER, W. Ecofisiologia vegetal. São Carlos: RiMa, 2004.

MARSCHNER, P. Mineral nutrition of higher plants. 3. ed. Amsterdam: Elsevier, 2012.

MASUTA, C. et al. Broad resistance to plant viruses in transgenic plants conferred by antisense inhibition of a host gene essential in S-adenosylmethionine-dependent transmethylation reactions. Proceedings of the National Academy of Sciences of the United States of America, v. 92, n. 13, p. 6117-6121, 1995.

MITTLER, R. Oxidative stress, antioxidants and stress tolerance. Trends in Plant Science, v. 7, n. 1, p. 405-410, 2002.

MULDER, E. G.; BOXMA, R.; VAN VEEN, W. L. The effect of molybdenum and nitrogen deficiencies on nitrate reduction in plant tissues. Plant and Soil, v. 10, n. 4, p. 335-355, 1959.
NAVARRO JÚNIOR, H. M.; COSTA, J. A. Expressão do potencial de rendimento de cultivares de soja. Pesquisa Agropecuária Brasileira, v. 37, n. 3, p. 275-279, 2002.

NELSON, L. R. Defining the seed-filling period in soybeans to predict yield. Crop Science, v. 26, n. 1, p. 132135, 1986.

O'BRIEN J.; BENKOVÁ, E. Cytokinin cross-talking during biotic and abiotic stress responses. Frontiers in Plant Science, v. 4, n. 11, p. 1-11, 2013.

REGUERA, M. et al. Stress-induced cytokinin synthesis increases drought tolerance through the coordinated regulation of carbon and nitrogen assimilation in rice. Plant Physiology, v. 163, n. 4, p. 1609-1622, 2013.

SOARES, L. H. Manejo fisiológico com base em tratamento de sementes e aplicação de organominerais via foliar para sistemas de alto potencial produtivo de soja. 130 f. 2013. Dissertação (Mestrado em Fitotecnia) - Escola Superior de Agricultura Luiz de Queiroz, Universidade de São Paulo, Piracicaba, 2014.

SOUZA, D. V. de et al. Análise pluviométrica da carta topográfica de Patos de Minas referente ao período de 1978 a 2003. In: REUNIÃO ANUAL DA SBPC, 57., 2005, Fortaleza. Anais eletrônicos... São Paulo: SBPC/ UECE, 2005. Available at: <http://www.sbpenet.org.br/ livro/57ra/>. Access on: Nov. 05, 2013.

TEISSEIRE, H.; GUY, V. Copper-induced changes in antioxidant enzymes activities in fronds of duckweed (Lemna minor). Plant Science, v. 153, n. 1, p. 65-72, 2000 .

UNITED STATES DEPARTMENT OF AGRICULTURE (USDA). Foreign Agricultural Service. Production, supply and distribution online. 2013. Available at: $<\mathrm{http}: / / \mathrm{www}$. fas.usda.gov/psdonline/psdQuery.aspx $>$. Access on: Nov. 05, 2013.

YU, X.; SUKUMARAN, S.; MÁRTON, L. Differential expression of the Arabidopsis Nial and Nia2 genes: cytokinin-induced nitrate reductase activity is correlated with increased Nial transcription and mRNA levels. Plant Physiology, v. 116, n. 3, p. 1091-1096, 1998.

ZAVALETA-MANCERA, H. A. et al. Cytokinin promotes catalase and ascorbate peroxidase activities and preserves the chloroplast integrity during dark-senescence. Journal of Plant Physiology, v. 164, n. 12, p. 1572-1582, 2007.

ZWACK, P. J.; RASHOTTE, A. M. Cytokinin inhibition of leaf senescence. Plant Signaling \& Behavior, v. 8, n. 7, p. 24737-1-e24737-7, 2013.

ZWACK, P. J.; RASHOTTE, A. M. Interactions between cytokinin signalling and abiotic stress responses. Journal of Experimental Botany, v. 66, n. 16, p. 48634871, 2015. 